\title{
Reliability and Factor Analysis of a Blackboard Course Management System Success: A Scale Development and Validation in an Educational Context
}

\author{
Adeyinka Tella \\ Faculty of Communication and Information Sciences, \\ University of Ilorin, Nigeria \\ tellayinkaedu@yahoo.com \\ Executive Summary
}

The suitability of 52 items for measuring Blackboard course management system success was investigated with the aim of validating the Blackboard CMS success scale in an educational context. Through a survey, the Blackboard course management system (BCMS) success scale was administered to 503 students at the University of Botswana.

Data collected were subjected to factor and reliability analysis. A total of 13 items were dropped from the pooled items resulting in the retention of 39 items on the final version. The scale has a Cronbach aloha reliability co-efficient of 0.91 . Exploratory factor analysis revealed the items on the final version of the scale loaded on eight factors accounted for $75 \%$ of the total scale variance. The reliability of each factor was as follows: Criterion Measure, $r=0.68 ; 87$ System Quality, $r$ $=0.68$; Content Quality, $r=0.61$; Service Quality, $r=0.50$; Teaching and Learning Quality, $r$ $=0.60$; Self-Regulated Learning, $r=0.74$; Intention to Use/Usage, $r=0.53$; User Satisfaction $r=$ 0.61 ; Net Benefits, $r=0.75$.

The empirical results emphasized the importance of assuming a multi-dimensional analytical approach. Therefore, it is important for educational institutions implementing Blackboard CMS to put emphasis on various system success levels. Theoretically, this study contributes significantly to the identification of educational oriented factors (teaching and learning quality, students' selfregulated learning) that may lead to Blackboard CMS by modifying the factors pioneered and revised by Delone and Mclean $(1992,2003)$. In summary, the study discovered that content quality, system quality, support service quality, teaching and learning quality, self-regulated learning, intention to use, user satisfaction, and net benefits are important dimensions for measuring Blackboard CMS success. The final instrument indicates adequate reliability and validity across educational context in e-learning systems.

Material published as part of this publication, either on-line or in print, is copyrighted by the Informing Science Institute. Permission to make digital or paper copy of part or all of these works for personal or classroom use is granted without fee provided that the copies are not made or distributed for profit or commercial advantage AND that copies 1) bear this notice in full and 2) give the full citation on the first page. It is permissible to abstract these works so long as credit is given. To copy in all other cases or to republish or to post on a server or to redistribute to lists requires specific permission and payment of a fee. Contact Publisher@InformingScience.org to request redistribution permission.
The study outcome implied that the Blackboard success measure developed in this study can be used to compare success for e-learning systems with specific factors (i.e., content quality, system quality, support service quality, teaching and learning quality, self-regulated learning, user satisfaction and net benefits). If any tertiary education institution implementing e-learning finds itself 
lacking in any of these dimensions or factors, then it may do a more detailed analysis and take necessary corrective actions. The Blackboard CMS success scale was designed to be applicable across a broad spectrum of e-learning systems and to provide a common framework for comparative analysis. Finally, implication for theory on the determining the success of any e-learning course management system and limitations of the study are provided.

Keywords: Factor analysis, E-learning, Course management system, WebCT/Blackboard, Scale development, Educational context, University of Botswana

\section{Introduction}

The explosion of information communication technologies (ICT) especially the increase in the use of the Internet has led to dramatic shifts in the way many higher educational institutions the world over deliver instruction. This has resulted in the use and adoption of e-learning, which is now gaining pace in many higher educational institutions worldwide. E-learning typically involves the use of ICT and computers to support learning (Learning Online, 2008; Raymond, 2000; Roffe, 2002). ICT is therefore a central construct that enables and/or supports the process of e-learning and has made remarkable progress in the last two or three decades (Rao, 2006). Course Management Systems are components of e-learning and their adoption for web-based instruction continues to increase. A course management system (CMS) is a software program or integrated platform that contains a series of web-based tools to support a number of activities and course management procedures (Severson, 2004). Examples of Course Management Systems are Blackboard, WebCT, eCollege, Moodle, Desire2Learn, and ANGEL.

Course management systems are a class of information systems that manage teaching and learning. Course management systems are developed to support and enhance the organizational processes of content creation, storage and retrieval, transfer, delivery and application. WebCT, now known as Blackboard, is such a course management system. Blackboard is an integrated, usermachine system for providing information or content to support teaching and learning.

Current research has shown that faculty members use these systems primarily to transmit course documents to students in resident courses (Ansorge \& Bendus, 2004; Dutton, Cheong, \& Park, 2004; Morgan, 2003; Woods, Baker, \& Hopper, 2004). This gives students convenient access to course materials and can lead to moderate increases in student performance (Grabe \& Christopherson, 2005). Nonetheless, many CMS features allow faculty members to create more complex learning activities than transmitting course content to students. It has been pointed out that academics and practitioners alike consider e-learning systems to be a valuable knowledge sharing and transfer tool (Y. S. Wang, Wang. \& Shee, 2007). However, researchers have not demonstrated a consistent relationship between information system investment and educational institution performance. Despite the increasing use of course management systems for teaching and learning, little attention has been given to examining the issues of its evaluation, which are central to e-learning implementation (Drury, 1998; Gatian, 1994). A limited number of studies have evaluated course management systems in e-learning environments.

Studies on course management systems or e-learning in general have largely focused on online content creation, the proportion of students using online content, online content development, securing content, the quality of content online, the management of student marks, and course materials (Educause Centre of Applied Research [ECAR], 2003; Eyitayo, 2005; Leem \& Lim, 2007; Lowe \& Kaplan, 2007; Morgan, 2003). The development of a measurement of success of a particular course management system's success (e.g., Blackboard) in an educational context deserves special attention because it is a contemporary information system whose measure has not been sufficiently reported in the literature. Furthermore, little research has been carried out to address the conceptualization and measurement of e-learning system success within the educational con- 
text. Whether or not traditional IS success models can be extended to assessing e-learning system success is rarely addressed (Y. S. Wang et al., 2007). Based on the DeLone and McLeans (2003) conceptual model of IS success, this study addresses the concern for a successful empirical measurement of an e-learning component system's success, i.e., a Blackboard course management system success construct.

It is pertinent to emphasise that the success of e-learning systems as pointed out by Y. S. Wang et al. (2007) cannot be evaluated using a single proxy construct (e.g., user satisfaction) or a singleitem scale (e.g., overall success). Similarly, it is agreed with Y. S. Wang et al. (2007) that the measure of e-learning systems success must incorporate different aspects of the Blackboard Course management system success construct if it is to be a useful diagnostic instrument. To assess the extent and specific nature of the Blackboard course management systems success, different dimensions of its construct must be defined both conceptually and operationally. An empirically validated instrument that identifies the dimensions of the Blackboard CMS Success construct can be of great value to both researchers and practitioners. It can enable researchers to identify various aspects of the Blackboard CMS Success construct and investigate the causality between the success of e-learning systems and its drivers (Y. S. Wang et al., 2007).

Generally, the focus has been on other information systems' successes and not course management system success. Moreover, previous studies have focused more on the output of information systems and not on the output of course management systems. Heeks (2000) approximates that $20-25 \%$ of ICT-related projects in developed countries are never implemented or are abandoned immediately following implementation, while a further $33 \%$ fail to achieve their major goals or they simply do not produce the desirable outcomes. Much of the research on course management systems is done in Europe, North America, and Asia but very few studies of this nature have been undertaken in Africa. Related studies in developing countries would provide a comparative picture with those in developed countries and help address some gaps in the literature in this area. This study addresses these issues by adapting Delone and Mclean's Model and then uses it to address the concern for an empirical measure of the success of the Blackboard course management system at the University of Botswana.

In terms of contribution to knowledge, the study develops a questionnaire instrument with psychometric properties for measuring a Blackboard course management system either in a corporate or educational setting. The study conceptualises the construct for determining Blackboard CMS success and its underlying dimensionality. Finally, it constitutes one of the pioneer studies to consider evaluation of a Blackboard course management system using the Delonne and Mclean model, thereby contributing to literature on the extension of the model.

\section{Theoretical Framework}

Research on assessing the evaluation of information systems has been ongoing for nearly three decades (Hussein, Abdu-Karim, Mohamed, \& Ahlan, 2007). However, the scope and approach of these IS evaluation studies has varied greatly, with little consensus on measures of IS success, thus complicating the comparison of results across studies and confounding the establishment of a cumulative research tradition (Gable, Sedera, \& Chan, 2003). This study was conducted in light of the need to search for the appropriate measure to evaluate the success of Blackboard course management systems. Just like e-commerce systems, enterprise resource planning systems, elearning systems, e-government systems, ATM systems, and more, course management systems are also a type of information system. Developing a model for determining Blackboard CMS success deserves special attention because it is a contemporary information system whose success evaluation has not been sufficiently reported in the literature. 
The literature has so far revealed variables and constructs used in evaluation/measurement of information systems success. These variables are most common to the constructs of IS success in the Delone and Mclean success model. Though many studies have attempted to extend the Delone and Mclean original IS success model, (e.g., Etezadi-Amoli \& Farhoomand, 1996; Goodhue \& Thompson, 1995; Guimaraes \& Igbaria, 1997; Igbaria \& Tan, 1997; Jurison, 1996; Li, 1997; Rai, Lang, \& Welker, 2002; Saarinen, 1996;Seddon, 1997) some have done so to overcome the shortcomings of the Delone and Mclean use construct, while others have done so to suit the context in which their studies have been conducted. The current study attempts to adapt the updated Delone and Mclean IS success model to develop an empirical measure of blackboard course management systems at the University of Botswana. This is supported by Wu and Wang's (2006) argument that, although Delone and Mclean proposed an updated conceptual IS success model, it clearly needs further validation before it can serve as a basis for the selection of appropriate IS measures.

In addition, research has to choose several appropriate success measures based on the objectives and the phenomena under investigation, as well as consider possible relationships among the success dimensions when constructing the measure. Going by this argument, some appropriate course management system success measures (e.g. teaching and learning quality and learners' self-regulation) are introduced to capture the phenomenon under study, namely, measures of Blackboard CMS system in an education setting/context. Teaching and learning quality was added to the constructs based on the fact that research has proved over the years that technology enhances and improves teaching and learning (ECAR, 2003; Morgan, 2003; US Department of Education, 2007). Moreover, this study was conducted in an educational setting focusing on teaching and learning. Therefore the needs to include variables that reflect this setting are germane.

Extant literature has shown that different studies have been conducted which focus on the evaluation of information systems. It is noted that various factors are involved when evaluating IS to determine its success, such as system quality, information quality, service quality, use, intention to use, user satisfaction, impact and net benefits of the system. Based on the initial work by Shannon and Weaver (1949), and by Mason (1978), Delone and Mclean's model (1992, 2003) became the focus of further theoretical research, especially in evaluating or measuring IS success. In fact, the model itself became the subject of research more than a tool of measurement. Delone and Mclean (2003) suggest that Mason's adoption of communication theory to accommodate information system measurements implied the need for success in measuring information communication. On the basis of this, Delone and Mclean produced a taxonomy of research and a model of IS/IT success. The components of the original model are system quality, information quality, user satisfaction, use, and individual and organisational impact. The primary conclusions of the original model were that the multidimensional nature of IS success requires careful attention to the definition and measurement of each aspect of this dependent variable (Delone \& Mclean, 1992, p. 88). It is important to measure the possible interactions among each of the success dimensions in order to isolate the effect of various independent variables with one or more of these dependent success dimensions. As Delone and Mclean suggested, a selection of success dimensions and measures is contingent on the objectives and context of the empirical investigation. Despite the multidimensional and contingent nature of IS success, an attempt should be made to reduce significantly the number of different measures used to measure the success of IS so that research results can be compared and findings validated.

Some weaknesses of the model have been noticed by researchers. For instance, Seddon (1997) argues that Delone and Mclean have "attempted to combine both process and causal explanations of IS success in their model." Seddon proceeds further to say that "after working with this model for some years, it has become apparent that the inclusion of both variance and process interpreta- 
tions in their model leads to so many potentially confusing meanings" (Seddon, 1997, p. 240). He argues for the removal of 'system use' as a success variable in the causal success model, claiming that 'use' is behaviour, appropriate for inclusion in a process model but not in a causal model. Seddon adds that 'use' must precede impacts and benefits, but it does not cause them (Seddon, 1997). However, Delone and Mclean disagree with Seddon believing that system usage is an appropriate measure of success in many cases (Delone \& Mclean, 2003). Pitt, Watson, and Kavan (1995) observed that "commonly used measures of IS effectiveness focus on the products rather than the services of the IS function. Thus, there is a danger that IS researchers can mis-measure or misevaluate IS success/effectiveness if they do not include in their assessment package a measure of IS service quality" (p. 173). Other researchers have agreed with this, citing the need for a service quality measure to be a part of IS success (Kettinger \& Lee 1995, Li 1997, Wilkin \& Hewitt 1999). The extension of the Delone and Mclean model with the Blackboard course management system constructs addresses these shortcomings.

The justification for the adaptation of Delone and Mclean model was based on the fact that: studies have attempted to use a high profile IS model such as the Delone and Mclean IS Success Model as a lens to determine the success of e-learning course management systems (e.g. Wu and Wang, 2007; Y. S. Wang et al., 2007). Most of the information system success models that have been used to determine information system success were borrowed from Delone and Mclean (2003). This same model was chosen and extended here because it has emerged to be a dominant framework for system evaluation research.

The perception of quality in teaching and learning by users with regard to a course management system is assumed to increase the use of the system and eventually to the success of the system. It is on this assumption that this research was designed to find if the quality of teaching and learning in an e-learning environment could determine the success of a Blackboard course management system. On the other hand, students' self-regulated learning is added, based on the observation that students utilise applications to construct more complicated meanings. However, not all learners are able to manage their learning process and master the content at hand, especially in elearning course management system environments (Neiderhuser \& Stoddart (2001). Thus Blackboard CMS can provide the support to guide learners in the use of the appropriate tools to help them acquire, for example, the strategic knowledge to collect and organize data and then demonstrate what they have learned (Niederhuser \& Stoddart, 2001). The extent to which the Blackboard CMS system causes learners to self-regulate their learning the better its success. Therefore, students' self-regulated learning is considered critical to the measure of success in an academic context. It is on this premise that student self-regulated learning is considered as one of the Blackboard CMS success constructs in this study.

\section{Success Constructs}

\section{Blackboard Course Management System Success (dependent variable)}

In this study, Blackboard course management system's success refers to the degree to which the person evaluating the system believes that the stakeholder (students) in whose interest the evaluation is being made is better off. In other words, the success of Blackboard CMS is the extent to which the system supports the fulfilment of the objectives that underpin its implementation at the University of Botswana in terms of its conformity to the resources (costs and time) assigned to it and the improvement of teaching and learning. Therefore, the success of the Blackboard course management system was determined by Blackboard CMS quality, content quality, support service quality, teaching and learning quality, student self-regulated learning, user satisfaction, and net benefits of Blackboard CMS. 
The sum of responses to all the eight Blackboard CMS success constructs in this study amount to the measure of Blackboard CMS success score. DeLone and McLean (2003) also suggest that "despite the multidimensional and contingent nature of IS success, an attempt should be made to reduce significantly the number of measures used to measure IS success, so that research results can be compared and findings validated" (p. 27). Consequent upon this, this study focuses mainly on the perspective of the students and uses the six updated IS success dimensions - Information Quality, System Quality, Service Quality, System Use, User Satisfaction, and Net Benefit - and the two additional ones that reflect an education setting - Teaching and Learning Quality and Student's Self-regulated Learning - to develop and validate a measurement model of Blackboard course management system success.

\section{System Quality (modified variable)}

This was taken directly from Delone and Mclean (2003) and refers to an overall quality of hardware and software and to the elements of the system that affect the end user and the way they interact and use the system. Therefore, system quality in this study refers to the elements of course management system that affects students at the University of Botswana in the way they interact and use the Blackboard course management system. The quality of the course management system in this study was determined by the degree of availability of the system on request, reliability (how Blackboard CMS is error free), and response time (the time taken to respond to the user's request, e.g., download time); these are examples of qualities that are valued by users of course management systems.

\section{Course Content Quality (modified variable)}

The course content quality in this study is defined as the judgment by the students of the degree to which the content on the Blackboard course management systems is valuable and useful, with regard to the defined needs of the student. The quality of course content is measured by its timeliness, relevance of course content to students' needs, usefulness to students, accuracy, importance, availability, and completeness. Information quality in IS research refers to output that the information system provides. Since the output of an information system is information in IS research, in this study, content quality is used because the output of a course management system is the content it provides. Therefore content is used instead of information.

\section{Service Quality (modified variable)}

Service quality is considered as the overall support delivered by the Blackboard CMS service provider or support rendered to the students in the environment or platform. It applies regardless of whether this support is delivered by the IS department, the Blackboard CMS support team, a new organizational unit, or outsourced to an Internet Service Provider (ISP).

\section{Intention to Use/Use of Blackboard CMS (modified variable)}

This construct is concerned with issues such as the number of hours spent on using the course management system by students. The use of the course management system was examined using both objective and subjective measurements. Objective measurements concentrated on the behavioural aspect of the system. Common objective measurements include the number of times used, frequency, intensity with respect to total services rendered or individual service encounters, and specific system functions used or not used. Also, the course management system was assessed subjectively, i.e., treated as a surrogate for perceived Blackboard CMS benefits. To this end, attitudinal measurements related to technology acceptance such as perceived system usefulness, ease of use, ease of learning, convenience of access, and user support were also considered. The intention to use is known to be a strong predictor of information system use in IS research (Davis, 
Bagozzi, \& Warshaw, 1989; Venkatesh, Morris, Davis, \& Davis, 2003). Therefore, a high intention to use is more likely to lead to high Blackboard CMS use, and then in turn increase net benefits and eventually success of the Blackboard CMS. This variable was assessed using indicators such as motivation for use, nature of use (voluntary and mandatory), frequency of use, access and availability.

\section{Users Satisfaction}

This construct is concerned with perceptions of satisfaction by the students in terms of individual outcomes on a pleasant-unpleasant continuum (Naylor, Prichard, \& Ilgen, 1980). User satisfaction in this study refers to the degree to which an individual user is satisfied with his or her overall use of the course management system under consideration. Collective findings from prior IS research have suggested that user satisfaction is a strong and critical manifestation of a system's success (Delone \& Mclean, 1992, 2003). User satisfaction has been extensively studied in IS research. As a result, several measurement inventories have been developed and validated. These inventories provide an adequate starting point for measuring user satisfaction in the targeted University of Botswana. In this study, this variable was measured using the modified user satisfaction scale where users (students) indicate how satisfied they are with using Blackboard CMS at the University of Botswana upon a four points scale. Indicators that were used to measure satisfaction include relevance, dependability, accuracy, usefulness, adequacy and effectiveness.

\section{Net Benefits}

Net benefits included the increased performance of individual student's learning or individual academic staff's teaching activities. For a University of Botswana student, important net benefits resulting from the use of a course management system included improvements in the learning outcome and performance, decision-making, and the quality of the students produced by the University through the system. It is the valuation of the benefits of course management systems to the students. Any use of resources, including the time taken in building course management system at the University of Botswana, learning to use, and using the course management system. To measure Net Benefits, one had to adopt some stakeholders (students) points of view about what is valuable and what is not about course management system as suggested by Seddon (1997). Therefore, net benefits in this study were measured by the perception of users on how valuable the course management system was to them. This was measured using the modified net benefit sub-scale used by S. Wang and Tang (2003).

\section{Learning and Teaching Quality (added variable)}

This is concerned with an improved quality of teaching and learning as perceived by the students. This is because the core business of course management systems is learning and teaching. Therefore, in this study the teaching and learning quality will mean the improvement in the way courses are delivered through the Blackboard CMS platform and the quality of the tutors' interaction with the students on the platform. This is measured by the perception of users (students) in terms of learning and teaching improvement on a four point scale.

\section{Learners' Self-Regulated Learning (added variable)}

Schunk and Zimmerman (1994) defined self-regulated learning as "the process whereby students activate and sustain cognitions and affects that are systematically oriented toward an attainment of their goals." Cognitive self-regulation can be taught to students (Hwang \& Liu, 1994). Blackboard CMS should inspire, motivate, and guide students to develop self-regulated learning cognitive skills. This means that students are guided in order to play an active role in learning, become self-organized, self-directed, independent, and actively participate in the learning process to con- 
struct their knowledge (Vovides, Sanchez-Alonso, \& Nickmans, 2007). According to the constructivist learning theory, students utilise open applications to construct more complicated meanings. However, not all learners are able to manage their learning process and master the content at hand, especially in e-learning environments. This is where Blackboard CMS can provide the support to guide learners in the use of the appropriate tools to help them acquire, for example, the strategic knowledge to collect and organize data and then demonstrate what they have learned (Niederhuser \& Stoddart, 2001). This construct is defined in this study as the way learners actively participate and take decisions regarding their learning. Therefore, with this variable, what was measured is the way learners self-regulated their learning under the course management system. This was measured using a modified learners' self-regulated scale developed by Schunk and Zimerman (1994).

\section{Research Methodology}

\section{Items Generation}

There are several potential measurement scales of the success for e-learning systems on which this study relied in developing the survey questionnaire. They include information system performance, enterprise systems success, enterprise resource planning system success, knowledge management system success, web success, e-learner satisfaction, user information satisfaction, end-user computer satisfaction, web user satisfaction, open source software system success, system use, information service quality, web quality, organizational benefits, information success in e-government (e.g., Abdalla, 2007; Bailey \& Pearson, 1983; Chien \& Tsaur, 2007; Delone \& Mclean, 1992; Doll \& Torkzadeh, 1988; Gable et al., 2003; Heo \& Han, 2003; Hussein et al., 2007; Ives, Olson, \& Baroudi, 1983; Kettinger \& Lee, 1994; Liu \& Arnett, 2000; Lohman, 2007; McKinney, Yoon, \& Zahedi, 2002; Mirani \& Lederer, 1998; Muylle, Moenaert, \& Despontin, 2004; Palvia, 1996; Rai et al.,2002; Saarinen, 1996; Segars \& Grover, 1998; C. M. Wang, 2004; S. Wang \& Tang, 2003). The implication of all these is that, most of these scales were reliable and valid. This in part enhances the validity and reliability of the instrument used in this study.

A total of 52 items representing the eight dimensions underlying the Blackboard CMS success construct were used to form the initial pool of items for the Blackboard CMS scale. To make sure that no important attributes or items were omitted, surveys and personal interviews on e-learning systems success were conducted with the assistance of university lecturers and one e-learning support staff member. They were asked to review the initial item list of the Blackboard CMS success scale; they recommended eliminating 13 items because of redundancy, and an additional three new items were suggested. After careful examination of the result of the surveys and interviews, the revised 39 items were further adjusted to make their wording as precise as possible and could be considered to constitute a complete scale for Blackboard CMS success measurement.

An initial Blackboard CMS success instrument involving 52 items (as shown in the Appendix), with the four criterion measures perceived overall success of the blackboard system as criteria, was developed using four points Likert-type scale. The four criterion measures (1. Overall the impact of Blackboard CMS on learning at UB has been positive; 2. Overall the impact of Blackboard CMS on me has been positive; 3. The performance of Blackboard CMS at UB to me as student is beneficial; 4. From my own perspective as UB student, use of Blackboard CMS is a success.) were used to analyze the criterion-related validity of the instrument and to measure the overall Blackboard systems success prior to detailed analysis. Respondents were required to rate the items in the scale based on 4 points Likert scale with end point of '4' Strongly Agree, and ' 1 ' Strongly Disagree; the two midpoints were ' 3 ' Agree and ' 2 ' Disagree. In addition to the Blackboard CMS success measuring items, the questionnaire contains demographic questions. 
All items from section A through I are close-ended items (See detail in Table 1 and Appendix). The NS - Not Sure/Indifferent was excluded from the response choice to overcome the neutral and don't know responses (Hussien et al., 2007) and, moreover, to avoid the distortion of results. The questionnaire was hand distributed to the participants. The questionnaire was pre-tested on a part of the envisage population to ascertain the validity and reliability of its items. It was assumed that most questions were based on previous empirical studies, had already been validated. This in part provides further justification for the validity of the items in the measure.

Table 1: Items Mapping

\begin{tabular}{|c|c|c|}
\hline Section A & $\begin{array}{l}\text { Items 1-4 } \\
\text { (Criterion Measure). }\end{array}$ & $\begin{array}{l}\text { The items covered the aspect } \\
\text { of Blackboard CMS success } \\
\text { at the University of Bot- } \\
\text { swana }\end{array}$ \\
\hline Section B & Items 5-9 & $\begin{array}{l}\text { The items in this section cov- } \\
\text { ered aspects of the Black- } \\
\text { board CMS quality. }\end{array}$ \\
\hline Section C & Items $10-13$ & $\begin{array}{l}\text { The items in this section cov- } \\
\text { ered the quality of the } \\
\text { Course content }\end{array}$ \\
\hline Section D & Items $14-16$ & $\begin{array}{l}\text { The items in this section cov- } \\
\text { ered Support Service Qual- } \\
\text { ity. }\end{array}$ \\
\hline Section E & Items 17-20 & $\begin{array}{l}\text { The items in this section cov- } \\
\text { ered Teaching and Learning } \\
\text { Quality. }\end{array}$ \\
\hline Section $\mathbf{F}$ & Items $21-24$ & $\begin{array}{l}\text { The items in this section cov- } \\
\text { ered Students }{ }^{e e} \text { Self- } \\
\text { Regulated learning. }\end{array}$ \\
\hline Section G & Items 25-29 & $\begin{array}{l}\text { The items in this section cov- } \\
\text { ered Intention to Use/Use of } \\
\text { CCMS. }\end{array}$ \\
\hline Section $\mathrm{H}$ & Items 30-34 & $\begin{array}{l}\text { The items in this section cov- } \\
\text { ered Use satisfaction. }\end{array}$ \\
\hline Section I & Items 35-39 & $\begin{array}{l}\text { The items in this section cov- } \\
\text { ered Perceived Net benefits } \\
\text { of Blackboard CMS. }\end{array}$ \\
\hline
\end{tabular}

\section{Key to the Scoring of the Scale}

This section demonstrates how this research can be used by a practitioner to evaluate their course management system. A successful course management system should have the following scores on each dimension and in sum as in the Table 2. 
Table 2: Scoring Interpretation of the Scale

\begin{tabular}{|c|c|c|}
\hline Section A & Total score in this section is $\mathbf{1 6}$. & $\begin{array}{l}\text { A score of } 13-16 \text { indicate highly success- } \\
\text { ful, 10-12 will indicate successful, } 7-9 \\
\text { indicate average success while any score } \\
\text { below } 7 \text { will indicate less successful. }\end{array}$ \\
\hline Section B & Total score is $\mathbf{2 0}$ & $\begin{array}{l}\text { A score of 16-20 indicate high system } \\
\text { quality while 12-15 indicate quality, 8-11 } \\
\text { indicate average and any score below } 7 \\
\text { indicate lower Blackboard CMS system } \\
\text { quality. }\end{array}$ \\
\hline Section C & Total score is 16 & $\begin{array}{l}\text { A score of 13-16 indicate high content } \\
\text { quality, 10-12 quality content, } 7-9 \text { aver- } \\
\text { age quality and any score below } 7 \text { indi- } \\
\text { cate lower content quality. }\end{array}$ \\
\hline Section D & Total score is 12 & $\begin{array}{l}\text { A score of 10-12 indicate high service } \\
\text { quality, 8-9 good quality, 6-7 average } \\
\text { service quality and any score below } 6 \\
\text { indicate lower service quality. }\end{array}$ \\
\hline Section $\mathbf{E}$ & Total score is 12 & $\begin{array}{l}\text { A score of 10-12 indicate high teaching } \\
\text { and learning quality, 8-9 good quality, } 6- \\
7 \text { average and any score below } 6 \text { indicate } \\
\text { lower teaching and learning quality. }\end{array}$ \\
\hline Section F & Total score is 16 & $\begin{array}{l}\text { A score of 13-16 indicate high self regu- } \\
\text { lation, 10-12 indicate good, any score } \\
\text { below 7-9 average self-reg. Any score } \\
\text { below } 7 \text { indicate lower self regulation. }\end{array}$ \\
\hline Section G & Total score is $\mathbf{2 0}$ & $\begin{array}{l}\text { A score between 16-20 indicate high } \\
\text { intention, 12-15 indicate good intention, } \\
\text { 8-11 indicate average intention while any } \\
\text { score below } 7 \text { indicate lower intention. }\end{array}$ \\
\hline Section $H$ & Total score is 24 & $\begin{array}{l}\text { A score between } 20-24 \text { indicate high sat- } \\
\text { isfaction. Score between 14-19 indicate } \\
\text { satisfaction; score between 11-13 indi- } \\
\text { cate average satisfaction while score be- } \\
\text { low } 10 \text { indicate lower satisfaction. }\end{array}$ \\
\hline Section I & Total score is 20 & $\begin{array}{l}\text { Score of } 16-20 \text { indicate high benefits. } \\
\text { Score between 12-15, indicate good bene- } \\
\text { fits and average benefits 8- } 11 \text {; while any } \\
\text { score below } 7 \text { indicate lower benefits. }\end{array}$ \\
\hline
\end{tabular}

Maximum score is 140. An overall score between 125-140 will indicate highly successful course management system. The scoring format is 4, 3, 2, 1, i.e., Strongly Agree 4...Strongly Disagree 1.

\section{Sample Selection Procedure}

The University main campus is situated in Gaborone, the capital city. During 2007/2008, the University had a total enrolment of 15,710 students of which 12,602 were fulltime. Approximately $51 \%$ of the students were females. Of the total enrolment, 14,777 were pursuing undergraduate programmes (University of Botswana, 2008). Currently, the University has seven faculties: Business, Education, Engineering and Technology, Humanities, Science, Social Sciences, and the Faculty of Health Sciences which is new. The seven faculties comprise over forty (40) 
departments. The University has a School of Graduate Studies and several specialised centres and research units. The University has a staff complement of 2,217 of which 827 are lecturing staff. The academic programs are offered at certificate, undergraduate and postgraduate levels (University of Botswana, 2008).

Within each faculty, a core course was chosen from each year of study excluding year 1. (Core courses are compulsory foundation courses which all students must take and pass before graduating from the University of Botswana). This means that 3 core courses were chosen from each faculty. The total number of students taking each of the core courses was identified and added to give a total for each faculty. From this total, $\pm 10 \%$ was taken for precision. The results obtained represent a sample for each faculty (See Tables 3 and 4). Overall, a total of 503 students represent the sample for the study.

Table 3: Distribution of Respondents' by Faculty $(\mathrm{N}=\mathbf{5 0 3})$

\begin{tabular}{|l|l|l|}
\hline Name of faculty & Frequency & Percentage \% \\
\hline Faculty of Business & 99 & 19.7 \\
\hline Faculty of Education & 89 & 17.7 \\
\hline $\begin{array}{l}\text { Faculty of Engineering Tech- } \\
\text { nology }\end{array}$ & 97 & 19.3 \\
\hline Faculty of Humanities & 52 & 10.3 \\
\hline Faculty of Science & 106 & 21.1 \\
\hline Faculty of Social Sciences & 60 & 11.9 \\
\hline Total & 503 & 100.0 \\
\hline
\end{tabular}


Table 4: Distribution of Respondents across Department $(\mathrm{N}=503)$

\begin{tabular}{|c|c|c|}
\hline Department & Frequency & Percentage \% \\
\hline Accounting and Finance & 76 & 15.1 \\
\hline Architecture and Planning & 13 & 2.6 \\
\hline Chemistry & 44 & 8.7 \\
\hline Civil Engineering & 51 & 10.1 \\
\hline Educational Foundations & 22 & 4.4 \\
\hline Electrical Electronics & 15 & 3.0 \\
\hline Environmental Science & 62 & 12.3 \\
\hline $\begin{array}{l}\text { Language and Social Science } \\
\text { Education }\end{array}$ & 5 & 1.0 \\
\hline $\begin{array}{l}\text { Library and Information Stud- } \\
\text { ies }\end{array}$ & 37 & 7.4 \\
\hline Management & 23 & 4.6 \\
\hline Mechanical Engineering & 16 & 3.2 \\
\hline Physical and Health & 58 & 11.5 \\
\hline $\begin{array}{l}\text { Political and Administrative } \\
\text { Studies }\end{array}$ & 46 & 9.1 \\
\hline Population Studies & 6 & 1.2 \\
\hline Primary Education & 4 & .8 \\
\hline Statistics & 8 & 1.6 \\
\hline TRS & 15 & 3.0 \\
\hline Urban and Regional Planning & 2 & .4 \\
\hline Total & 503 & 100.0 \\
\hline
\end{tabular}




\section{Scale Purification}

\section{Item analysis and reliability estimates}

The 35-item instrument (with the four criterion items excluded, i.e., 1. Overall the impact of Blackboard CMS on learning at UB has been positive; 2. Overall the impact of Blackboard CMS on me has been positive; 3 . The performance of Blackboard CMS at UB to me as student is beneficial; 4. From my own perspective as UB student, use of Blackboard CMS is a success) were refined by analyzing the pooled data; that is, the data collected from e-learners across different faculties and departments at the University of Botswana were considered together. Because the primary purpose of this study was to develop a general instrument capable of reliably and accurately measuring Blackboard course management system success in various educational context e-learning systems, the pooling of the sample data is considered appropriate (Y. S. Wang et al., 2007).

The first step in purifying the instrument was to calculate the coefficient alpha and the item-tototal- correlations used to delete garbage items (Cronbach, 1951). To avoid spurious part-whole correlation, the criterion used in this study for determining whether to delete an item was the item's corrected item-to-total correlation. An iterative sequence of computing Cronbach's alpha coefficients and item-to-total correlations was executed for each Blackboard CMS success dimension. Following Y. S. Wang et al.'s, (2007) procedure, the corrected item-to-total correlations were plotted in descending order, and items with item-to-total correlations below 0.4 , or whose correlations produced a substantial or sudden drop in the plotted pattern were eliminated. Because each item is corrected item-to-total correlation was above 0.4 (see Table 5), no item was eliminated in this stage. The 39-item Blackboard CMS success instrument has reliability (Cronbach's alpha) of 0.91.The table below contains information about item purification on the questionnaire.

Table 5a: Summary of Results from Scale Purification

\begin{tabular}{|c|c|c|c|c|}
\hline Notation & Dimension/Item & Reliability & $\begin{array}{l}\text { Factor loading } \\
\text { of items on di- } \\
\text { mension to } \\
\text { which they be- } \\
\text { long }\end{array}$ & $\begin{array}{l}\text { Corrected item- } \\
\text { to-total correla- } \\
\text { tion }\end{array}$ \\
\hline $\begin{array}{l}\text { CM1 } \\
\text { CM2 } \\
\text { CM3 } \\
\text { CM4 }\end{array}$ & $\begin{array}{l}\text { Criterion Measure } \\
\text { Overall the impact of blackboard course manage- } \\
\text { ment system on learning at UB has been positive } \\
\text { Overall the impact of blackboard course c man- } \\
\text { agement system on me has been positive } \\
\text { The performance of blackboard course manage- } \\
\text { ment system at UB to me as student is beneficial } \\
\text { From my own perspective as UB student, use of } \\
\text { blackboard CMS is a success. }\end{array}$ & 0.68 & $\begin{array}{l}0.872 \\
0.770 \\
\\
0.737 \\
0.825\end{array}$ & $\begin{array}{l}0.689 \\
0.538 \\
0.651 \\
0.699\end{array}$ \\
\hline $\begin{array}{l}\text { SQ5 } \\
\text { SQ6 } \\
\text { SQ7 } \\
\text { SQ8 } \\
\text { SQ9 }\end{array}$ & $\begin{array}{l}\text { Blackboard CM System Quality } \\
\text { Blackboard CMS availability is very high } \\
\text { Blackboard CMS is easy to use } \\
\text { Blackboard CMS is user-friendly } \\
\text { Blackboard CMS provides interactive features } \\
\text { between users and system } \\
\text { Blackboard CMS provides high-speed access to } \\
\text { Information }\end{array}$ & 0.68 & $\begin{array}{l}0.632 \\
0.858 \\
0.832 \\
0.784 \\
0.896\end{array}$ & $\begin{array}{l}0.362 \\
0.674 \\
0.652 \\
0.671 \\
0.636\end{array}$ \\
\hline
\end{tabular}




\begin{tabular}{|c|c|c|c|c|}
\hline Notation & Dimension/Item & Reliability & $\begin{array}{l}\text { Factor loading } \\
\text { of items on di- } \\
\text { mension to } \\
\text { which they be- } \\
\text { long }\end{array}$ & $\begin{array}{c}\text { Corrected item- } \\
\text { to-total correla- } \\
\text { tion }\end{array}$ \\
\hline $\begin{array}{l}\text { CQ10 } \\
\text { CQ11 } \\
\text { CQ12 } \\
\text { CQ13 }\end{array}$ & $\begin{array}{l}\text { Content Quality } \\
\text { I think course content on Blackboard is always } \\
\text { presented in a useful format } \\
\text { Blackboard CMS provides up-to-date information } \\
\text { Blackboard CMS provides course con- } \\
\text { tent/information that seems to be exactly what I } \\
\text { need. } \\
\text { Blackboard CMS provides content/information } \\
\text { relevant to my discipline. }\end{array}$ & 0.61 & $\begin{array}{l}0.758 \\
0.818 \\
0.842 \\
0.893\end{array}$ & $\begin{array}{l}0.408 \\
0.557 \\
0.615 \\
0.585\end{array}$ \\
\hline $\begin{array}{l}\text { SerQ14 } \\
\text { SerQ15 } \\
\text { SerQ16 }\end{array}$ & $\begin{array}{l}\text { Service Quality } \\
\text { The Blackboard CMS system provides a proper } \\
\text { level of on-line assistance and explanation. } \\
\text { The IT department/e-learning support staffs are } \\
\text { always available for consultation relating to black- } \\
\text { board. } \\
\text { The IT department/e-learning support staffs pro- } \\
\text { vide satisfactory support to users using the Black- } \\
\text { board at UB. }\end{array}$ & 0.50 & $\begin{array}{l}0.751 \\
0.759 \\
0.712\end{array}$ & $\begin{array}{l}0.532 \\
0.479 \\
0.487\end{array}$ \\
\hline $\begin{array}{c}\text { TLQ17 } \\
\text { TLQ18 } \\
\text { TLQ19 }\end{array}$ & $\begin{array}{l}\text { Teaching and Learning Quality } \\
\text { Learning through Blackboard CMS is stress free. } \\
\text { Learning through Blackboard CMS is easier. } \\
\text { Blackboard CMS aides active learning }\end{array}$ & 0.60 & $\begin{array}{l}0.802 \\
0.902 \\
0.820\end{array}$ & $\begin{array}{l}0.516 \\
0.546 \\
0.539\end{array}$ \\
\hline $\begin{array}{l}\text { SRL20 } \\
\text { SRL21 } \\
\text { SRL22 } \\
\text { SRL23 }\end{array}$ & $\begin{array}{l}\text { Self-Regulated Learning } \\
\text { Blackboard CMS allows me to ask myself questions } \\
\text { to make sure I understand the material and courses } \\
\text { I have been studying and offered. } \\
\text { Blackboard CMS helps me to practice exer- } \\
\text { cises/answer assignment and quiz questions. } \\
\text { Blackboard CMS helps me decide on the things I } \\
\text { will need to do to learn before offering a course. } \\
\text { Blackboard CMS enables me to control my learning } \\
\text { progress }\end{array}$ & 0.74 & $\begin{array}{l}0.879 \\
\\
0.7865 \\
0.871 \\
0.828\end{array}$ & $\begin{array}{l}0.421 \\
0.650 \\
0.484 \\
0.732\end{array}$ \\
\hline
\end{tabular}


Table 5b: Summary of Results from Scale Purification

\begin{tabular}{|c|c|c|c|c|}
\hline Notation & Dimension/Item & Reliability & $\begin{array}{l}\text { Factor loading } \\
\text { of items on di- } \\
\text { mension to } \\
\text { which they be- } \\
\text { long }\end{array}$ & $\begin{array}{l}\text { Corrected item- } \\
\text { to-total correla- } \\
\text { tion }\end{array}$ \\
\hline & Intention to use/ Blackboard CMS usage & 0.53 & & \\
\hline ITU24 & The frequency of my using Blackboard CMS is high & & 0.855 & 0.654 \\
\hline ITU25 & $\begin{array}{l}\text { If Blackboard CMS were not mandatory, I would } \\
\text { still use it. }\end{array}$ & & 0.899 & 0.644 \\
\hline ITU27 & $\begin{array}{l}\text { I spend many hours per week with Blackboard } \\
\text { CMS. }\end{array}$ & & 0.878 & 0.638 \\
\hline ITU28 & If time permit, I will spend long hours per week with & & 0.950 & 0.632 \\
\hline US29 & $\begin{array}{l}\text { Blackboard CMS. } \\
\text { Assuming I have access to Blackboard CMS, I in- } \\
\text { tend to use it }\end{array}$ & 0.61 & 0.767 & 0.589 \\
\hline US30 & User Satisfaction & & 0.795 & 0.407 \\
\hline US31 & The Blackboard CMS is efficient & & 0.823 & 0.705 \\
\hline US32 & I find the Blackboard CMS dependable & & 0.884 & 0.529 \\
\hline US33 & $\begin{array}{l}\text { I am satisfied with the accuracy of the Blackboard } \\
\text { CMS. }\end{array}$ & 0.75 & $\begin{array}{l}0.904 \\
0.831\end{array}$ & $\begin{array}{l}0.634 \\
0.464\end{array}$ \\
\hline US34 & $\begin{array}{l}\text { The output of the Blackboard CMS (content) is } \\
\text { presented in a useful format }\end{array}$ & & 0.863 & 0.460 \\
\hline NB35 & $\begin{array}{l}\text { The Blackboard CMS is adequate to meet the in- } \\
\text { formation processing needs of my area of responsi- } \\
\text { bility }\end{array}$ & & 0.832 & 0.558 \\
\hline NB36 & Over-all, I am satisfied with the Blackboard CMS & 0.11 & 0.854 & 0.695 \\
\hline NB37 & Net Benefits & & & \\
\hline & $\begin{array}{l}\text { The Blackboard CMS helps me improve my learn- } \\
\text { ing performance }\end{array}$ & & 0.900 & 0.842 \\
\hline $\begin{array}{l}\text { NB38 } \\
\text { NB39 }\end{array}$ & $\begin{array}{l}\text { The Blackboard CMS helps me think through prob- } \\
\text { lems. }\end{array}$ & & 0.842 & 0.670 \\
\hline & $\begin{array}{l}\text { The Blackboard CMS enables the University to } \\
\text { respond more quickly to change regarding teaching } \\
\text { and learning. }\end{array}$ & & & \\
\hline & $\begin{array}{l}\text { The Blackboard CMS helps the University to pro- } \\
\text { duce better products. }\end{array}$ & & & \\
\hline & $\begin{array}{l}\text { The Blackboard helps the University save cost relat- } \\
\text { ing to teaching and learning. }\end{array}$ & & & \\
\hline
\end{tabular}

\section{Instrument Reliability}

Reliability of an instrument is the degree of consistency of an instrument to measure what it is expected to be measured (Best \& Khan, 1998, 2006). To ensure the reliability of the questionnaire used in this study, $a$ test re-tests reliability method of two weeks interval using Cronbach alpha was adopted to determine both internal consistency reliability and overall reliability of each of the factors or variables identified in the study. The correlation co-efficient of 0.76 and above suggests the questionnaire is highly reliable and can be recommended for future use (Marsh \& Hocevar, 1988). The results demonstrate that all variables display similar results for internal consistency reliability. Reliability in this study was achieved by examining whether the same patterns or the- 
matic constructs are replicated in different settings. Reliability was evaluated by assessing the internal consistency of the items representing each factor using Cronbach Alpha. The 39 item questionnaire had a reliability of 0.91 , exceeding the minimum standard of 0.80 suggested for basic research (S. Wang \& Tang, 2003) and 0.76 suggested by Marsh and Hocevar (1988). The reliability of each factor was as follows: Criterion Measure, $r=0.68$; System Quality, $r=0.68$; Content Quality, $r=0.61$; Service Quality, $r=0.50$; Teaching and Learning Quality, $r=0.60$; SelfRegulated Learning, $r=0.74$; Intention to Use/Usage, $r=0.53$; User Satisfaction $r=0.61$; Net Benefits, $r=0.75$ (See Table 3). These indicate that all the sections of the measure in this study are reliable for use except the Service quality, which has a lower reliability co-efficient. However, these were used in this study but the service quality section needs to be revalidated in the event of future use.

\section{Content Validity}

Content validity implies that the questionnaire considers all aspects of the constructs by generating items that exhaust the domain (Churchill, 1979). This study provides a conceptual framework of Blackboard CMS bringing out the eight constructs (Blackboard CMS Quality, Content Quality, Support Service Quality, Learning and Teaching Quality, Student Self-Regulated Learning, Intention to Use/Use, User Satisfaction, and Net Benefits) underlying the Blackboard CMS success construct in an attempt to enhance content validity. Part of the effort to ensure the content validity of the questionnaire used in this study was giving the instrument to experts. The recommendations of the experts in e-learning authenticate the relevance of the items in the questionnaire to the content of what is being measured in the study. Therefore, the procedure used in conceptualizing the Blackboard success measure construct, generating items, and purifying the Blackboard Success measures suggest that the questionnaire has a strong content validity.

\section{Criterion Validity}

Criterion related validity refers to concurrent validity in this study where the total scores on the Blackboard CMS instrument and scores on the valid criterion are measured at the same time (Hussein et al., 2007). Besides the overall items, the questionnaire included four criterion measures of overall success of the Blackboard course management system. These are:

Overall, the impact of Blackboard course management system on my institution has been positive.

Overall, the impact of Blackboard course management system on me has been positive.

Overall, the performance of Blackboard course management system at UB is beneficial.

Overall, the Blackboard course management system at UB is successful.

Moreover, the criterion related validity was assessed by the correlation between the total scores on the instrument (sum of the 35 items) and the measures of valid criterion (sum of the four criterion items). Usually, a positive relationship between the total score and the valid criterion of the instrument implies the capability of the instrument to measure the Blackboard CMS success construct. A higher correlation (e.g., 0.65-0.99; at a significant level of 0.000) represents an acceptable criterion-related validity of the questionnaire (Campbell \& Fiske, 1959; Hussein et al., 2007). In other words, a higher correlation suggests a strong correspondence between the criterion measures and the success dimensions of the questionnaire (Gable et al., 2003; Kerlinger, 1988). In this study, the 39 items on the questionnaire had a criterion-related validity of 0.71 at significant level of 0.01 , which represents acceptable criterion validity. 


\section{Construct Validity}

Construct validity refers to the extent to which an instrument accurately measures or represents a construct and produces an observation distinct from that produced by a measure of another construct (US Environmental Protection Agency, 2007). To achieve the construct validity of the instrument used in this study, factor analysis was performed using a principal component method of analysis. It is expected that the results were similar to those obtained by the items of each similar construct of the original instruments where the items were adapted. All loading is expected to be in the good to excellent range (Comrey, 1971) thereby authenticating the suitability of the instrument for use in this study. An exploratory factor analysis was performed to examine the factor structure of the 39 item questionnaire. Prior to identifying the factor structure of the Blackboard CMS success construct using factor analysis, a chi-square value of 6412.72 and significance level of 0.05 were obtained. This suggests that the inter-correlation matrix contains sufficient common variance to make factor analysis worthwhile (See Table 6). The responses were examined using the principal component factor analysis as the extraction technique. An iterative sequence of factor analysis was also executed. At this stage none of the items were deleted. At the end of the factor analysis procedure, 9 factors of the 39 items on the questionnaire were obtained. The eight factors were interpreted as Blackboard Course Management System Quality, Content Quality, Support Service Quality, Intention to Use, User Satisfaction, Net Benefit, Teaching and Learning Quality, Student Self-regulated Learning, explaining $75 \%$ of the variance in the data set. Table 5 summarises the factor loading for the 39 items questionnaire. The significant loading of all the items on the single factor indicates unidimensionality. It was observed that no cross-loading was found. This supports the discriminant validity of the questionnaire.

Table 6: Descriptive Statistics and Inter-correlation Matrix between the factors $(N=503)$

\begin{tabular}{|c|c|c|c|c|c|c|c|c|c|c|c|c|}
\hline Construct & Mean & $\begin{array}{l}\text { Std. } \\
\text { Devia- } \\
\text { tion }\end{array}$ & $\mathbf{N}$ & Ev sc & $\begin{array}{l}\text { S. } \\
\text { Qual. }\end{array}$ & $\begin{array}{l}\text { C. } \\
\text { Qual. }\end{array}$ & $\begin{array}{l}\text { Ser. } \\
\text { Qual. }\end{array}$ & $\begin{array}{l}\text { T \& } \\
\text { Learn } \\
\text {.Qual. }\end{array}$ & $\begin{array}{l}\text { S.R } \\
\text { Learn. }\end{array}$ & ITU & $\begin{array}{l}\text { U. } \\
\text { Sat. }\end{array}$ & $\begin{array}{l}\text { Net } \\
\text { Bene. }\end{array}$ \\
\hline Crit Meas. & 102.4314 & 23.987 & 503 & 1.000 & & & & & & & & \\
\hline S. Qual. & 14.874 & 2.874 & 503 & .464 & 1.000 & & & & & & & \\
\hline C. Qual. & 11.169 & 2.315 & 503 & .497 & .588 & 1.000 & & & & & & \\
\hline $\begin{array}{l}\text { Service } \\
\text { Qual. }\end{array}$ & 7. 411 & 2.694 & 503 & .367 & .336 & .418 & 1.000 & & & & & \\
\hline T\& L Qual. & 7.986 & 2.067 & 503 & .497 & .506 & .525 & .393 & 1.000 & & & & \\
\hline S.R Learn. & 10.451 & 2.472 & 503 & .511 & .331 & .421 & .342 & .485 & 1.000 & & & \\
\hline ITU & 13.161 & 2.551 & 503 & .482 & .356 & .368 & .273 & .436 & .424 & 1.000 & & \\
\hline U Sat. & 16.041 & 3.904 & 503 & .615 & .571 & .553 & .389 & .567 & .515 & .535 & 1.000 & \\
\hline N. Bene. & 13.456 & 3.389 & 503 & .500 & .296 & .343 & .242 & .393 & .511 & .423 & .551 & 1.000 \\
\hline
\end{tabular}

Legend- Crit.Sc- Criterion Measure, S.Qual.-System Quality, C.Qual.- Content Quality, Service Qual.-Service Quality, T\&L Qual- Teaching and Learning Quality, S.R. Learn-Students' SelfRegulated Learning, ITU-Intention to use, USat-User Satisfaction, N.Bene-Net Benefits 


\section{Convergent Validity}

The previous factor analysis has demonstrated the discriminant and convergent validity. In the light of this, the correlation matrix approach was used to evaluate these two validities of the Blackboard CMS success instrument. Convergent validity tests whether the correlations between measures of the same factor are different from zero and large enough to warrant further investigation of discriminant validity (Y. S. Wang et al., 2007). Table 4 reveals that correlation exists between the overall success score of Blackboard CMS and other factors/measures. The data indicates that User Satisfaction had the highest correlation matrix $(r=0.62)$ with Blackboard course management system success evaluation. This is followed by students' Self-Regulated Learning ( $\mathrm{r}$ $=0.51)$ and Net Benefits $(\mathrm{r}=0.50)$. Correlation of other factors with Blackboard evaluation reveals Content Quality and Teaching and Learning Quality as having $(r=0.49)$, Intention to Use/Use $(r=0.48)$, System Quality $(r=0.46)$ while Service Quality had the lowest correlation ( $\mathrm{r}$ $=0.37$ ). This indicates that all these factors have an association with Blackboard CMS success and with one another. These correlations are significantly higher than zero and large enough to proceed with discriminant validity analysis. Discriminant validity for each item is tested by counting the number of times that the item correlates higher with items of other factors than with items of its own theoretical factor.

\section{Conclusion}

This study proposed a Blackboard CMS success measurement scale and empirically tested the relationships between the indentified constructs. In summary, the study discovered that Content Quality; System Quality, Support Service Quality, Teaching and Learning Quality, SelfRegulated Learning, Intention to Use/Use, User Satisfaction and Net Benefits are important dimensions for measuring Blackboard CMS success. The final instrument indicates adequate reliability and validity across educational context in e-learning systems.

\section{Implication for Practice}

This study provides several implications for Blackboard e-learning success and effectiveness. The empirical results emphasize the importance of assuming a multi-dimensional analytical approach. Therefore, it is important for educational institutions implementing Blackboard CMS to put emphasis on various system success levels. As indicated by Delone and Mclean (2003) information quality, system quality, and service quality belong to the system developing level; system use, user satisfaction, and net benefit belong to the system effectiveness influence level. Establishing strategies to improve only one success variable is considered an incomplete strategy if the effects of the others are not considered. The results of this study will encourage Blackboard CMS managers/administrators to include the measures of Content Quality, System Quality, Service Quality, Teaching and Learning Quality, Self-Regulated Learning, Intention to Use/Use, User Satisfaction and Net Benefits in their evaluation techniques of e-learning systems.

Aside from an overall evaluation, the Blackboard success measure developed in this study can be used to compare success for e-learning system with specific factors (i.e. Content Quality, System Quality, Support Service Quality, Teaching and Learning Quality, Self-Regulated Learning, User Satisfaction and Net Benefits). If any tertiary education institution implementing e-learning finds itself lacking in any of these dimensions or factors, then it may do a more detailed analysis and take necessary corrective actions. The Blackboard CMS success scale was designed to be applicable across a broad spectrum of e-learning systems, and to provide a common framework for comparative analysis. 
In ensuring success of e-learning systems in tertiary education institutions, e-learning policy makers should borrow ideas from the results on this study. This should contribute to the measurement of success of their e-learning system.

This study has brought about new measures and evaluation models required to measure success with contemporary information systems as suggested by Ishman (1996) and Sedera, Gable, and Chan (2003). In this respect, instead of relying on instruments and measures that were validated with what are now outdated information systems (Jurison, 1996, pp. 75-159; Saarinen, 1996), information system researchers can now make use of contemporary IS measures validated in this study to determine IS success.

Moreover, this study has endeavoured to bridge the gap identified as a paucity of research into Blackboard CMS success evaluations. The study has responded to the call made by researchers (e.g. Y. S. Wang et al., 2007) for more studies to investigate other aspects of e-learning. This study has adapted and modified dimensions of success in the updated Delone and Mclean IS Success Model to determine or evaluate the Blackboard course management system at the University of Botswana.

\section{Implications for Theory}

Many factors have been employed as measures of IS success and most of these have been measured in previous studies. However, in previous IS success literature, information system success is a multi-dimensional construct, which cannot be measured only through user satisfaction or system use. This study has conceptualized the construct of Blackboard CMS success, provided a validated construct and its underlying dimensionality, and developed a questionnaire instrument with desirable psychometric properties for measuring Blackboard course management system success.

Theoretically, this study contributes significantly to the identification of educationally oriented factors (teaching and learning quality, students' self-regulated learning) that may lead to Blackboard CMS success by a modification of the factors pioneered and revised by Delone and Mclean (2003). In addition, the evidence should assist e-learning support team and administrators in universities and other educational institutions in implementing as well as improving the existing systems through the educational factors identified. When making an effort to ensure elearning/blackboard course management system success, educational institutions must make sure the Blackboard CMS strategy and educational objectives are aligned, administrators are trained and equipped with IT knowledge and strategy, top administrative staff are involved in all activities pertaining to IT/Blackboard system use and implementation organization wide, and resources such as time, money, and manpower are sufficiently and properly allocated.

Furthermore, the numerous factors examined provide a strong base for the understanding of Blackboard CMS success. The study has also bridged the gap of limited assessment or evaluation of IS success which is very rare in an educational setting. It has also contributed to the body of research on course management system which the literature revealed to be concentrated in Europe, North America and Asia.

\section{Limitations}

It is observed and noted that aside from quality of teaching and learning with self-regulated learning which reflects the core business of e-learning, there are still other relevant variables that can be added. In terms of scope, this study is confined to the University of Botswana. Therefore, future research could include more tertiary educational institutions in Botswana that are implementing course management system. 


\section{References}

Abdalla, I. (2007). Evaluating effectiveness of e-blackboard system using TAM framework: A structural analysis approach. AACE Journal, 15(3), 279-287.

Ansorge, C. J., \& Bendus, O. (2004). The pedagogical impact of course management systems on faculty, students, and institutions. In R. Brunning, C. Horn, \& L. M. Pitlyk Zillig (Eds.), Web-based learning: What do we know? Where do we go? (pp.169-190). Greenwich, CT: Information Age Publications.

Bailey, J. E., \& Pearson, S. W. (1983). Development of a tool for measuring and analyzing computer user satisfaction. Management Science, 29(5), 530-545.

Best, J. W., \& Kahn, J. V. (1998). Research in education (9th ed.). Boston, MA: Allyn and Bacon.

Best, J. W., \& Kahn, J. V. (2006). Research in education (10th ed.). Boston, MA: Allyn and Bacon.

Campbell, D. R., \& Fiske, D. W. (1959). Convergent and discriminant validation by multitrait-multimethod matrix. Psychological Bulletin, 56(2), 81-105.

Chien, S. W., \& Tsaur, S. M. (2007). Investigating the success of ERP system: Case studies in three Taiwanese high-tech industries. Computers in Industry, 58(8-9), 783-793.

Churchill, G. A. (1979). A paradigm for developing better measures of marketing constructs. Journal of Marketing Research, 16(1), 64-73.

Comrey, A. L. (1971). An introduction to factor analysis. New York: Academic Press.

Cronbach, L. J. (1951). Coefficient alpha and the internal structure of tests. Psychometrika, 16(13), 297334.

Davis, F. D., Bagozzi, R. P., \& Warshaw, P. R. (1989). User acceptance of computer technology: A comparison of two theoretical models. Management Science, 35(8), 982-1003.

Delone, W. H., \& Mclean, E. R. (1992). Information system success: The quest for the dependent variable. Information System Research, 3(1), 61-95.

Delone, W. H., \& Mclean, E. R. (2003). The Delone and Mclean information system success: A ten years update. Journal of Management Information Systems, 19(4), 30-36.

Doll, W. J., \& Torkzadeh, G. (1988). The measurement of end-user computing satisfaction. MIS Quarterly, $12(2), 259-274$.

Drury, D. H. (1998). A hierarchical structural model of information systems success. Infor, Feb-May. Retrieved January 15, 2008, from: http://findarticles.com/p/articles/mi qa3661/is_199802

Dutton, W. H., Cheong, P. H., \& Park, N. (2004). An ecology of constraints on e-learning in higher education: The case of a virtual learning environment. Prometheus, 22(2), 131-149.

Educause Center for Applied Research [ECAR]. (2003). Supporting e-learning in higher education. Educause Report. Retrieved April 5, 2007, from http://www.educause.edu.ecar

Etezadi-Amoli, J., \& Farhoomand, A. F. (1996). A structural model of end user computing satisfaction and user performance. Information \& Management, 30, 65-73.

Eyitayo, O. T. (2005). Experimenting e-learning with a large class. International Journal of Education and Development using Information and Communication Technology (IJEDICT), 1(3), 160-171.

Gable, G. G., Sedera, D., \& Chan, T. (2003). Enterprise systems success: A measurement model. Proceedings of the twenty-fourth international conference on information systems (pp. 576-591), December 1417 , Seattle, Washington, USA.

Gatian, A. W. (1994). Is user satisfaction a valid measure of system effectiveness? Information and Management, 26(3), 119-131.

Goodhue, D. L., \& Thompson, R. L. (1995). Task-technology fit and individual performance. MIS Quarterly, 19, 213-236. 
Guimaraes, T., \& Igbaria, M. (1997). Client/server system success: Exploring the human side. Decision Sciences, 28(4), 851-875.

Grabe, M., \& Christopherson, K. (2005). Evaluating the advantages and disadvantages of providing lecture notes: The role of internet technology as a delivery system and research tool. Internet and Higher Education, 8, 291-298.

Heeks, R. (2000). Reinventing government in information age. London: Routledge Press.

Heo, J., \& Han, I. (2003). Performance measure of information systems (IS) in evolving computing environments: An empirical investigation. Information and Management, 40(4), 243-256.

Hussein, R., Abdu-Karim, N. S., Mohamed, N., \& Ahlan, A. R. (2007). The influence of organizational factors on information system success in e-government agencies in Malaysia. Electronic Journal of Information Systems in Developing Countries EJISDC, 29(1), 1-17.

Hwang, B., \& Liu, Y. (1994). A study of proportional reasoning and self-regulation instruction on students' conceptual change in conceptions of solution. ERIC Document Reproduction Service No. ED 368-574).

Igberia, M., \& Tan, M. (1997). The consequence of information technology acceptance on subsequent individual performance. Information \& Management, 32, 113-121.

Ishman, M. D. (1996). Measuring information success at the individual level in cross-culture environments. Information Resource Management Journal, 9(4), 16-28.

Ives, B., Olson, M. J., \& Baroudi, J. J. (1983). The measurement of user information satisfaction. Communications of the ACM, 26(10), 785-793.

Jurison, J. (1996). The temporal nature of IS benefits: A longitudinal study. Information and Management, $30(2), 75-79$.

Kerlinger, F. N. (1988). Foundation of behaviour research. New York: Harper and Row.

Kettinger, W., \& Lee, C. (1995). Perceived service quality and user satisfaction with the information services function. Decision Sciences, 25(5/6), 737-65.

Learning Online. (2008). An introduction to e-learning. Retrieved July 12, 2010, from http://pblonline.org/LearnOnline/elearning.htm

Leem, J., \& Lim, B. (2007). The current status of e-learning and strategies to enhance educational competitiveness in Korean Higher education. International Review of Research in Open and Distance Learning, 8(1), 1-18.

Li, E. Y. (1997). Perceived importance of information system success factors: A meta-analysis of group differences. Information and Management, 32, 15-28.

Liu, C., \& Arnett, K. P. (2000). Exploring the factors associated with Web site success in the context of electronic commerce. Information and Management, 38(1), 23-33.

Lohman, M. C. (2007). Effects of information distribution strategies and student performance and satisfaction in a web-based CMS. International Journal of Scholarship of Teaching and Learning, 1(1). Retrieved February 27, 2008, from http://www.geogiasouther.edu/ijsot

Lowe, N. J., \& Kaplan, R. (2007). Reflections on the changing use of Web-CT in a business communication course. Proceedings of the 9th Annual Conference on World Wide Web Applications, 5-7 September 2007, Johannesburg, South Africa (http://www.zaw3.co.za).

Marsh, H. W., \& Hocevar, D. (1988). A new, more powerful approach to multitrait-multimethod analyses: Application of second order confirmatory factor analysis. Journal of Applied Psychology, 73, 107-117.

Mason, R. M. (1978). The economics and cost benefit of analysis services - The case of information analysis centers. In M. C. J. Elton, W. V. Lucas, \& D. W. Conrath (Eds.), Evaluating new telecommunication services (pp 303-324). New York: Plenum Press. 
McKinney, V., Yoon, K., \& Zahedi, F. M. (2002). The measurement of web-customer satisfaction: An expectation and disconfirmation approach. Information Systems Research, 13(3), 296-315.

Mirani, R., \& Lederer, A. L. (1998). An instrument for assessing the organizational benefits of is projects. Decision Sciences, 29, 803-838.

Morgan, G. (2003). Faculty use of course management systems. Educause Research Study, 2, 45-46.

Muylle, S., Moenaert, R., \& Despontin, M. (2004). The conceptualization and empirical validation of web site user satisfaction. Information and Management, 41(5), 543-560.

Naylor, J. C., Prichard, R. D., \& Ilgen, D. R. (1980). A theory of behaviour in organizations. London: Academic Press.

Niederhauser, D., \& Stoddart, T. (2001). Teacher's instructional perspectives and use of educational software. Teacher \& Teacher Education, 17, 15-31.

Palvia, P. C. (1996). A model and instrument for measuring small business user satisfaction with information technology. Information and Management, 31(3), 151-163.

Pitt, L., Watson, R., \& Kavan, C. (1995). Service quality: A measure of Information systems effectiveness. MIS Quarterly, 19(2), 173-185.

Rai, A., Lang, S. S., \& Welker, R. B. (2002). Assessing the validity of IS success models: An empirical test and theoretical analysis. Information Systems Research, 13(1), 50-69.

Rao, S., (2006). Distance education and the role of IT in India. The Electronic Library, 24(3), 225-236.

Raymond, F., (2000). Delivering distance education through technology - A pioneer's experience. Campus-Wide Information Systems, 17(1), 49-55.

Roffe, I., (2002). E-learning - Engagement, enhancement and execution. Quality Assurance in Education, $10(1), 40-50$.

Saarinen, T. (1996). An expanded instrument for evaluating information systems success. Information and Management, 31(2), 103-118.

Schunk, D., \& Zimmerman, B. (1994). Self-regulation of learning and performance. Issues and educational applications. Hillsdale, NJ: Eribaum.

Sedera, D., Gable, G., \& Chan, T. (2003). Survey design: Insights from a public sector-ERP impact study. J. Hanisch, D. Falconer, S. Horrocks, \& M. Hillier (Eds.), Proceedings of Seventh the Pacific Asian Conference on Information Systems, Adelaide, Australia, July 10-13, pp. 595-610.

Seddon, P. B. (1997). A respecification and extension of the DeLone and McLean model of IS success. Information Systems Research, 8(3), 240-253.

Segars, H. A., \& Grover, V. (1998). Strategic planning success: An investigation of the construct and its measurement. MIS Quarterly, 22(2), 139-163.

Severson, A. (2004). Faculty support required for the implementation of a new learning management system. Thesis submitted to the Simon Fraser University for the degree of Master in Distributed Learning.

Shannon, C. E., \& Weaver, W. (1949). The mathematical theory of communication. Urbana: University of Illinois Press.

University of Botswana. (2008). Facts and figures. University Fact Book.

US Department of Education. (2007). Connecting students to advance courses online: Innovations in education. WestEd, US Department of Education Office of Innovation and Improvement.

US Environmental Protection Agency. (2007). Program evaluation glossary. Retrieved June 26, 2008, from http://wwwepa.gov/evaluate/glossary/c-esd.htm

Venkatesh, V., Morris, M. G., Davis, F. D., \& Davis, G. B. (2003). User acceptance of information technology: Toward a unified view. MIS Quarterly, 27, 425-478. 
Vovides, Y., Sanchez-Alonso, S., \& Nickmans, V. M. (2007). The use of e-learning course management system to support learning strategies and to improve self-regulated learning. Educational Research Review, 2(1), 64-74.

Wang, C. M. (2004). Taking online courses in the United States: The perspectives of Asian students from China, Korea, Singapore, and Taiwan. Proceedings of the E-Learn 2004 conference: World conference on e-learning in corporate, government, healthcare, \& higher education (pp. 2,466-2,468). Norfolk, VA: Association for the Advancement of Computing in Education.

Wang, S., \& Tang, T. I. (2003). Assessing customer perceptions of Web sites service quality in digital marketing environments. Journal of End User Computing, 15(3), 14-31.

Wang, Y. S., Wang. H. Y., \& Shee, D. Y. (2007). Measuring e-learning systems success in an organizational context: Scale development and validation. Computers in Human Behavior, 23(4), 1792-1808.

Wilkin, C., \& Hewitt, B. (1999). Quality in a respecification of Delone and McLean's IS success model. In Mehdi Khorzrowpour (Ed.), Proceedings of 1999 IRMA International conference. Hershey, PA: Idea Group Publishing, 1999, 663-672.

Woods, R., Baker, J. D., \& Hopper, D. (2004). Hybrid structures: Faculty use and perception of Web-based courseware as a supplement to face-to face instruction. Internet and Higher Education, 7(4), 281-297.

Wu, J. H., \& Wang, Y. M. (2006). Measuring KMS success: A respecification of the DeLone and McLean's model. Information \& Management, 43, 728-739.

\section{Appendix}

The Initial Measure of Blackboard Course Management System Success

\begin{tabular}{|l|l|l|l|l|l|}
\hline A. & Criterion Measure (Success of Blackboard CMS) & SA & A & D & SD \\
\hline 1. & $\begin{array}{l}\text { Overall the impact of Blackboard CMS on learning at UB has } \\
\text { been positive }\end{array}$ & & & \\
\hline 2. & Overall the impact of Blackboard CMS on me has been positive & & & & \\
\hline 3. & $\begin{array}{l}\text { The performance of Blackboard CMS at UB to me as student is } \\
\text { beneficial }\end{array}$ & & & \\
\hline 4. & $\begin{array}{l}\text { From my own perspective as UB student, use of Blackboard CMS } \\
\text { is a success. }\end{array}$ & & & \\
\hline
\end{tabular}

\begin{tabular}{|l|l|l|l|l|l|}
\hline \multicolumn{2}{|c|}{ B. Blackboard Course Management System (Blackboard CMS) Quality } & SA & A & D & SA \\
\hline 5. & Blackboard CMS availability is very high & & & & \\
\hline 6. & Blackboard CMC is easy to use & & & & \\
\hline 7. & Blackboard CMS is user-friendly & & & & \\
\hline 8. & Blackboard CMS provides interactive features between users and & & & & \\
\hline 9. & Blackboard CMS provides high-speed access to Information. & & & & \\
\hline 10 & The Blackboard has attractive features to appeal to the users. & & & & \\
\hline 11 & The Blackboard provides a personalized information presentation. & & & & \\
\hline
\end{tabular}




\begin{tabular}{|c|c|c|c|c|c|}
\hline \multicolumn{2}{|c|}{ C. Content Quality } & $\mathbf{S A}$ & $\mathbf{A}$ & $\mathbf{D}$ & SD \\
\hline 12 & I think course content is always presented in a useful format & & & & \\
\hline 13. & Blackboard CMS provides up-to-date information & & & & \\
\hline 14. & $\begin{array}{l}\text { Blackboard CMS provides course content/information that seems } \\
\text { to be exactly what I need. }\end{array}$ & & & & \\
\hline 15. & $\begin{array}{l}\text { Blackboard CMS provides content/information relevant to my dis- } \\
\text { cipline. }\end{array}$ & & & & \\
\hline 16. & The Blackboard CMS provides content you need at the right time. & & & & \\
\hline 17. & $\begin{array}{l}\text { The Blackboard CMS provides information that is easy to under- } \\
\text { stand. }\end{array}$ & & & & \\
\hline
\end{tabular}

\begin{tabular}{|c|c|c|c|c|c|}
\hline D. & Service Quality & SA & $\mathbf{A}$ & $\mathbf{A}$ & D \\
\hline 18. & $\begin{array}{l}\text { The Blackboard CMS system provides a proper level of on-line assis- } \\
\text { tance and explanation. }\end{array}$ & & & & \\
\hline 19. & $\begin{array}{l}\text { The IT department/e-learning support staff are always available for } \\
\text { consultation. }\end{array}$ & & & & \\
\hline 20. & $\begin{array}{l}\text { The IT department/e-learning support staff provide satisfactory sup- } \\
\text { port to users using the Blackboard CMS at UB. }\end{array}$ & & & & \\
\hline 21. & $\begin{array}{l}\text { The Blackboard CMS developers interact extensively with users dur- } \\
\text { ing the development of the e-learning system. }\end{array}$ & & & & \\
\hline 22. & $\begin{array}{l}\text { The IS department responds in a cooperative manner to your sugges- } \\
\text { tion for future enhancements of Blackboard system. }\end{array}$ & & & & \\
\hline
\end{tabular}

\begin{tabular}{|c|l|l|l|l|l|}
\hline E. & Teaching and Learning Quality & A & SA & A & D \\
\hline 23. & $\begin{array}{l}\text { Learning through a Blackboard course management system is } \\
\text { stress free. }\end{array}$ & & & & \\
\hline 24. & $\begin{array}{l}\text { Learning through a Blackboard course management system is } \\
\text { easier. }\end{array}$ & & & \\
\hline 25. & Blackboard course t management system aides active learning & & & \\
\hline
\end{tabular}

\begin{tabular}{|c|l|l|l|l|l|}
\hline F. & Self-regulated learning & SA & A & D & SD \\
\hline 26 & $\begin{array}{l}\text { Blackboard CMS allows me to ask myself questions to make sure I } \\
\text { understand the material and courses I have been studying and of- } \\
\text { fered. }\end{array}$ & & & & \\
\hline 27. & $\begin{array}{l}\text { Blackboard CMS helps me to practice exercises/answer assignment } \\
\text { and quiz questions. }\end{array}$ & & & \\
\hline 28. & $\begin{array}{l}\text { Blackboard CMS helps me decide on the things I will need to do to } \\
\text { learn before offering a course. }\end{array}$ & & & & \\
\hline 29. & Blackboard CMS enables me to control my learning progress & & & \\
\hline
\end{tabular}




\begin{tabular}{|c|c|c|c|c|c|}
\hline \multicolumn{2}{|r|}{ G. Intention to use/Blackboard Course Management Usage } & $\mathbf{S A}$ & $\mathbf{A}$ & $\mathbf{D}$ & SD \\
\hline 30 . & $\begin{array}{l}\text { The frequency of my using Blackboard course management system } \\
\text { is high }\end{array}$ & & & & \\
\hline 31. & $\begin{array}{l}\text { If course management system were not mandatory, I would still } \\
\text { use it. }\end{array}$ & & & & \\
\hline 32. & $\begin{array}{l}\text { I spend many hours per week with Blackboard course manage- } \\
\text { ment system. }\end{array}$ & & & & \\
\hline 33. & $\begin{array}{l}\text { If time permit, i will spend long hours per week with Blackboard } \\
\text { course management system. }\end{array}$ & & & & \\
\hline 34. & Assuming I have access to Blackboard CMS, I intend to use it & & & & \\
\hline 35 & The Blackboard CMS usage is voluntary & & & & \\
\hline 36 & I depend on the Blackboard CMS & & & & \\
\hline
\end{tabular}

\begin{tabular}{|l|l|l|l|l|l|}
\hline \multicolumn{2}{|c|}{ H. User Satisfaction withBlackboard CMS } & SA & A & D & SD \\
\hline 37. & The course content management system is efficient & & & & \\
\hline 38. & I find the Blackboard CM system dependable & & & & \\
\hline 39. & I am satisfied with the accuracy of the system & & & & \\
\hline 40. & The output of the system(content) is presented in a useful format & & & & \\
\hline 41. & $\begin{array}{l}\text { The system is adequate to meet the information processing needs of } \\
\text { my area of responsibility }\end{array}$ & & & \\
\hline 42. & Over-all, I am satisfied with the system & & & \\
\hline 43. & $\begin{array}{l}\text { Most of the users bring a positive attitude or towards the Black- } \\
\text { board CMS function. }\end{array}$ & & & & \\
\hline 44. & $\begin{array}{l}\text { I think that the perceived utility about the Blackboard CMS is } \\
\text { high. }\end{array}$ & & & \\
\hline
\end{tabular}

\begin{tabular}{|c|c|c|c|c|c|}
\hline \multicolumn{2}{|c|}{ I. Net Benefits } & SA & $\mathbf{A}$ & D & SD \\
\hline 45. & $\begin{array}{l}\text { The Blackboard course management system helps me improve my } \\
\text { learning performance }\end{array}$ & & & & \\
\hline 46. & The Blackboard CMS helps me think through problems. & & & & \\
\hline 47. & $\begin{array}{l}\text { The Blackboard CMS enables the University to respond more } \\
\text { quickly to change regarding teaching and learning. }\end{array}$ & & & & \\
\hline 48. & $\begin{array}{l}\text { The Blackboard CMS helps the University to produce better prod- } \\
\text { ucts. }\end{array}$ & & & & \\
\hline 49. & $\begin{array}{l}\text { The Blackboard course management system helps the University } \\
\text { save cost relating to teaching and learning. }\end{array}$ & & & & \\
\hline $\mathbf{5 0}$ & $\begin{array}{l}\text { The Blackboard CMS helps the university to speed up transactions } \\
\text { or shorten product cycles. }\end{array}$ & & & & \\
\hline 51 & $\begin{array}{l}\text { 33. The Blackboard CMS helps the university increase return re- } \\
\text { lating to teaching and learning investment }\end{array}$ & & & & \\
\hline 52 & 34. The Blackboard CMS helps the university to achieve its goal. & & & & \\
\hline
\end{tabular}




\section{Biography}

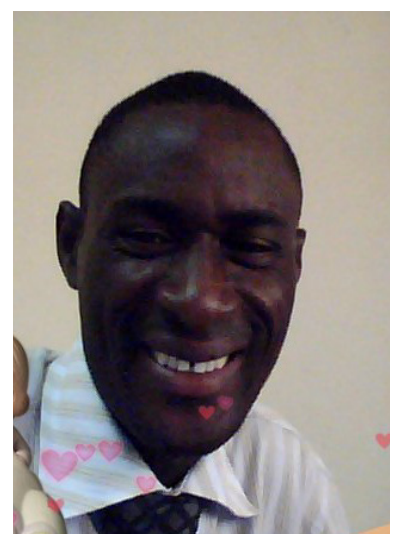

Adeyinka TELLA is a senior lecturer in the Department of Library and Information Science, Faculty of Communication and Information Sciences, University of Ilorin, Nigeria. Tella is a commonwealth scholar who finished his $\mathrm{PhD}$ in September 2009 from the Department of Library and Information Studies; University of Botswana under the supervision of Prof. S.M. Mutula. He has written and published articles mostly in International reputable refereed journals together with chapters in books. He is one of the contributors to an information science reference "Cases on Successful E-learning Practices in the Developed and Developing World: Methods for the Global Information Economy" $\mathrm{He}$ is now working on a new information science reference text: "Library and Information Science in Developing Countries: Contemporary Issues." The expected date of publication is July 2011.

Currently, he is the Associate Editor International Journal of Library and Information Science, and Editor-in-Chief- International Journal of Information Management and Processing. His research areas include e-learning, information literacy, information communication technology, psychology of information, etc. This paper is one of the summaries from his thesis. 